\title{
Demographics and Demand Holding Cash Money
}

\author{
Munawwarah S. Mubarak ${ }^{1}$, I Made Benyamin ${ }^{2}$, Sanusi Fattah ${ }^{3}$, Paulus Uppun ${ }^{4}$ \\ ${ }^{I}$ Economic Department, Faculty of Economics \& Business, Hasanuddin University, Makassar, Indonesia. \\ ${ }^{2}$ Economic Department, Faculty of Economics \& Business, Hasanuddin University, Makassar, Indonesia. \\ ${ }^{3}$ Economic Department, Faculty of Economics \& Business, Hasanuddin University, Makassar, Indonesia. \\ ${ }^{4}$ Economic Department, Faculty of Economics \& Business, Hasanuddin University, Makassar, Indonesia.
}

\begin{abstract}
This study examines whether the variable demand for holding cash money affected directly or indirectly by the variable family size through financial investment and consumption of durable goods. This research is basically done to verify the theory of demand for money from a macroeconomic perspective toward a more microeconomic nature and the kind of basic research that is both deductive and inductive (inferential statistical-inductive). The sampling method performed proportionate stratified random sampling method through a questionnaire survey to collect information from respondents (sampling) which is expected to represent the entire population. Basic stratification is the type of work / livelihood, which is divided into seven main types of work. The analytical method used is the estimation of simultaneous equation system (SEM). The results showed that the size of the family variables Influence demand for holding cash money showed a positive and significant influence either directly or indirectly through financial investment only. Keywords: demography, family size, demand for holding cash money.
\end{abstract}

\section{Introduction}

School of thought about the money demand is weak, all the theory of demand for money has always been associated with macroeconomic variables [1], [2], [3], [4], [5].Many macroeconomic literature which already contained the theoretical and empirical aspects of the demand for money in many countries [3], [4]. In a study of monetary theory tends to be weak, especially the study of the demand for money. All theories of money demand is approached with macro variables. For example in the classical theory, when discussing money, Fisher ignore the behavior of individuals and microeconomic theory. Instead he looked at the money through the lens of a broad aggregate. He sees the general economic trend, such as how much money and credit in the economy increased, but he did not see how individuals and institutions to get money [6]. The drawback is that excessive macro approach to monetary theory. He did not want to look at the dynamics of monetary economics. As a result, the implications of the basics of monetary (central bank authorities) looked very dictate the need for public money, because not based on a robust microeconomic foundations. Not surprisingly, since the past until today, the source of the economic crisis in principle is always triggered by the bubbling action (bubling) in the financial sector [7].

But the question arises, in this connection, if the money supply is sufficient to represent the public demand. Or even an imbalance in money supply which is always on top of money demand in the short term certainly lead to inflation. As a result, there are always errors in understanding the amount of money needed by the people [7]. Even the monetarist doctrine that money neutrality (money supply equals money demand) in the long term must be questioned [7], [8]. Of course the authority of the central bank as the party who supplied the money only see the macro variables that affect the demand for money in running one of its main tasks to maintain the stability of the economy with the assumption that, in the long run, money supply equals money demand. Came the criticism, is it true that the demand for public money voluntarily is equal to the money supply. This issue is crucial for the study of the determinants of demand for real money is not only determined on the macro aspects, but also should be on the side of the variable microeconomics [1], [7], [9], [10], [11], [12 Unfortunately, the application of the classical theory of money demand-neoclassical eg Quantity Theory of Money from Keynes and Irving Fisher to Baumol-Tobin in macroeconomic analysis nevertheless always stated that the money supply is equal to demand money [6].

Another factor of the micro aspects that will determine the demand for money, among others, is the number of dependents in the family. Various studies on the effect of family size and socio-economic conditions on the demand for money a household show the same or different results [13], [14], [15]. Family size has positive influence on the consumption of durable goods and the demand for households holding cash money but negatively related to financial investment. Upon reaching the top, then the head of the household family size will affect negatively. Attanasio, Guiso and Jappelli (2001) conducted research on the saving behavior of households. The study shows that the relationship between the number of dependents in the household with the financial investment is negative, then the impact on family relationships size and demand for holding money ash is positive [16] 
From the description of the problem demand for money seems very interesting to conduct a study on the analysis of money demand with micro foundations and household approach. The tendency of monetary theory that mutter money supply equals money demand makes researchers interested in assessing whether it was true money supply equals money demand, when seen from a micro-scale ?. For that reason the focus of this study is about the size of a family observation micro aspects that influence the demand for holding cash money Household.Based on the description of the background of the problem, then the formulation of the subject matter of this research is: Do family size affect the demand for money either directly or indirectly through financial investment as and consumption of durable goods. The purpose of this research is: To quantify, identify and analyze how much influence family size to money demand (DHCM), either directly or indirectly through financial investment as and consumption of durable goods.

\section{Theory, Empirical Study And Metodology}

Hyunt (1979), states that the number of families and the dependency ratio affect the amount of savings, consumption and demand for money by analyzing about saving behavior of households in Korea with independent variables the average length of the school (year), family size, dependency ratio and revenue-related significantly to money demand, savings and consumption. For old school and earnings were positively associated family size and dependency ratio associated negative [17]. The results of research conducted in accordance with Tin (2000), especially for income levels. Tin (2000) showed that the change in conditions sociodemografi (age, education, race, gender, children, the status of the region and marital status) will have a significant influence on the behavior of individual savings in the money market. This is supported by the results of the regression stating that the desire to save between different individuals, depending on their socioeconomic conditions [13].

Tin J (2010) analyze the influence of income, savings, inheritance and demographic factors (age, education, family size, gender) to money demand in the United States in 2009. The study concluded that the variable income, savings, inheritance positive and significant impact on the the demand for money as well as demographic factors such as age, family size, gender significant effect on the demand for money [14]. Nugroho and Widiastuti (2003) analyzed the effect of religiosity, income and family dependents to savings in Yogyakarta. The results of the OLS estimates show that the number of family dependents to have a significant negative effect on savings. According to the hypothesis of the life cycle, the savings is determined by income, tax rate, dependency and retirement ratio, the amount of credit and socioeconomic conditions (age, education level, race, sex, children, the status of the region, marital status and welfare and so forth [18], [19], [20]. This study is expected to represent the entire population by using a survey method. Survey method here is to use media questionnaire to collect information from respondents (sampling). The unit of analysis of this study is the head of the household who live in the city of Makassar and has major revenue as responsible financially. Exogenous variables in this study is the variable family size. Namely intervening variables Y1 and Y2 are financial investment is the consumption of durable goods as well as endogenous variables which Y3 is a demand for holding cash money

$\mathrm{Y} 1=\mathrm{f}(\mathrm{X}), \mathrm{Y} 2=\mathrm{f}(\mathrm{X}, \mathrm{Y} 1), \mathrm{Y} 3=\mathrm{f}(\mathrm{X}, \mathrm{Y} 1, \mathrm{Y} 2)$

Where:

$\mathrm{X}=$ family size

$\mathrm{Y} 1=$ Financial Investment

Y2 = Consumption of durable goods

Y3 = Demand for holding cash money

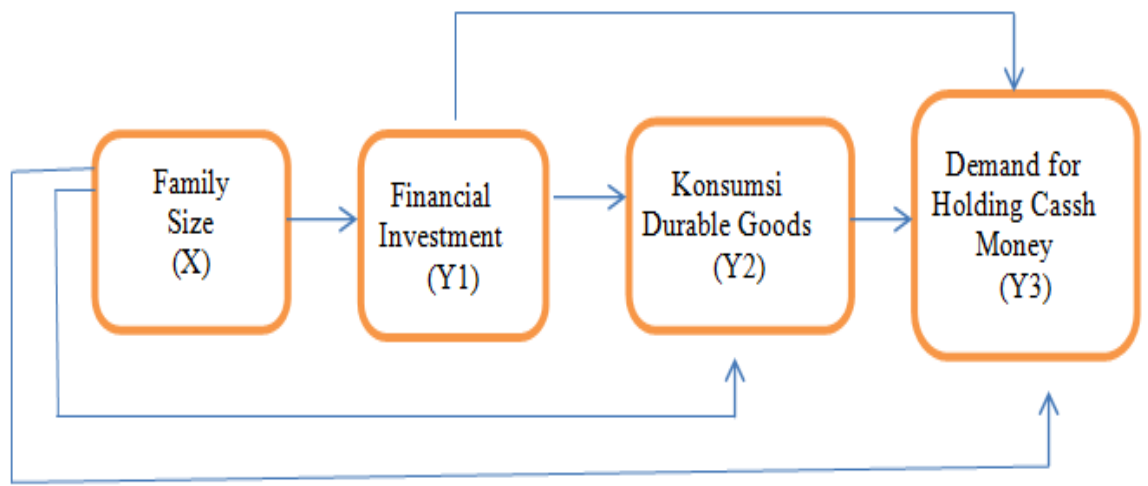

Figure 1 The conceptual framework of research 
Variable income either $\mathrm{X}$ is family size is an exogenous variable. Namely intervening variables $\mathrm{Y} 1$ and $\mathrm{Y} 2$ are financial investment is the consumption of durable goods as well as endogenous variables roomates Y3 is a demand for holding cash money. $\mathrm{Y} 1=\mathrm{f}(\mathrm{X}), \mathrm{Y} 2=\mathrm{f}(\mathrm{X}, \mathrm{Y} 1), \mathrm{Y} 3=\mathrm{f}(\mathrm{X}, \mathrm{Y} 1, \mathrm{Y} 2)$ Where: $\mathrm{X}=$ Family size, $\mathrm{Y} 1=$ Financial Investment, $\mathrm{Y} 2=$ Consumption of durable goods, with $\mathrm{Y} 3=$ Demand for holding cash money

$\mathrm{Y} 1=\alpha 0 \mu 1+\alpha 1 \mathrm{X}+\mathrm{Y} 2=\Omega 0+\Omega 1 \mathrm{X}+\mu 12$

$\mathrm{Y} 3=\lambda 0+\lambda 1 \mathrm{X}+\mu 123(4.1)$

Where: $\Omega 0=\beta 0+\alpha 0 \beta 1$ is a constant; $\Omega 1=\beta 2+\alpha 1 \beta 1$ is the total effect on the y2 x consisting of a direct influence on the $\mathrm{y} 2 \mathrm{x}$ of $\beta 2$ plus indirect effect through y1 of $\alpha 1 \beta 1 ; \alpha 0 \gamma 1 \lambda 0=\gamma 0+++\alpha 0 \beta 1 \gamma 2 \beta 0 \gamma 2$ is a constant; $\lambda 1=\gamma 3+\alpha 1 \gamma 1+\beta 2 \gamma 2+\alpha 1 \beta 1 \gamma 2$ is the total effect $\mathrm{x}$ to $\mathrm{y} 3$ which consists of direct influence $\mathrm{x}$ to $\mathrm{y} 3$ of $\gamma 3$ plus indirect effect only through y1 of $\alpha 1 \gamma 1$ plus indirect effect only through y 2 of $\beta 2 \gamma 2$ plus indirect effect through y1 and y2 for $\alpha 1 \beta 1 \gamma 2$ [21].

Reviews These variables are then defined as follows:

1. Demand for money / holding cash money (Y3) is the average amount of cash that must be provided heads of households in the form of cash to meet all the needs of household consumption of non-durable goods.

2. Consumption of durable goods (Y2) is the amount of expenses incurred for purchasing durable goods and for consumer use or for investment in economically normal family size is one year or better on credit or cash. To that end, the variable consumption of durable goods is measured by the total value of the rupiah against the purchase of various assets that have been done within 5 (five) years.

3. Financial Investment (Y1) is the amount of money set aside for savings, bank deposits and the purchase of shares or securities and insurance policies. Therefore, the financial variables of this investment as measured by the total value of financial assets that have been done within 5 (five) years.

4. Family size (X) is the number of family members dependents and settled for 3 (three) months, measured in the souL.

\section{Result And Disscussion}

Table 1. Function Estimation Results Table Financial Investment (Y1), Consumption of durable goods (Y2), and Demand for holding cash money (Y3)

\begin{tabular}{|l|l|l|l|}
\hline $\begin{array}{l}\text { Directions between } \\
\text { Variables Influence }\end{array}$ & $\begin{array}{l}\text { Regression } \\
\text { coefficients }\end{array}$ & t-Statistic & Probability \\
\hline $\mathrm{X}=>Y_{1}$ & $0,051^{*}$ & 10,476 & 0,000 \\
\hline $\mathrm{Y}_{1}=>Y_{2}$ & 0,489 & 1,145 & 0,252 \\
\hline $\mathrm{X}=>Y_{2}$ & $0,15^{*}$ & 4,122 & 0,000 \\
\hline $\mathrm{Y}_{1}=>Y_{3}$ & $0,351^{*}$ & 3,641 & 0,000 \\
\hline $\mathrm{Y}_{2}=>Y_{3}$ & $0,08^{*}$ & 1,898 & 0,058 \\
\hline $\mathrm{X}=>Y_{3}$ & $0,109^{*}$ & 0,000 \\
\hline $\begin{array}{l}* \\
\text { R significantly on } \alpha=5 \% ;\end{array}$ \\
$\begin{array}{l}\mathrm{R}^{2} Y_{1}=0,607 ; \mathrm{R}^{2} Y_{2}=0,102 ; \mathrm{R}^{2} Y_{3}=0,341 \\
\mathrm{~N}=289\end{array}$
\end{tabular}

Analysis and Implications of Family Size Effect on Demand for holding cash money Both Direct and Indirect through Financial Investment and Consumption of Durable Goods The direct effect of family size on the demand for holding cash money showed positive and significant impact. This means that the greater the number of family dependents will increase the demand for holding cash money, otherwise the fewer the number of family dependents will lower demand for holding cash money. This is due to the increasing number of cash that will be used to meet the needs of both yourself, spouse, child or other family members are dependent households.

These results are consistent with the initial hypothesis which states that the family size directly affects positively and significantly to the demand for holding cash money. In addition, these results are also consistent with the theory Dunbar (2014) which states that there is a positive relationship between family size and the demand for money. Respondents who are married and have children tend to take more money than those who are not married and do not have children, it is because more and more cash to be used to meet the needs of both the keperluaan yourself, spouse, child or other family member who became dependent households. The indirect influence of family size to the demand for holding cash money through financial investment showed no significant effect on the whole. That is a lot or a little number of dependent family members will not be affected by changes in financial investment. Furthermore, also found no link between the financial investment and the demand for holding cash money. Many dependents do not affect a person in terms of financial investment and asked for cash in order to meet the needs of his family. These results are not in accordance with the initial hypothesis which states that family size in a positive indirect effect on the demand for holding cash money through financial investment. This result is also not in line with the theory of Tobin (1956) and Dunbar (2014) 
which states that the number of dependents will cause a person to take more than saving money. This suggests that family size is positively related indirectly to the demand for money when analyzed influence through savings / financial investment. In addition, the indirect effect of family size on the demand for holding cash money through the consumption of durable goods showed no significant effect on the whole. That is a lot or a little number of members kelaurga dependents will not be affected by changes in the consumption of durable goods. Furthermore, also found no link between the consumption of durable goods and the demand for holding cash money. At least the savings due to the number of dependents do not cause increased consumption and seta does not affect the demand for cash.

These results are not in accordance with the initial hypothesis which states that working hours indirectly positively affect the demand for holding cash money through the consumption of durable goods. This result is also not in line with the theory of Tobin (1956) and Dunbar (2014) which states that family size is positively related indirectly to the demand for money when analyzed influence through savings / financial investment and consumption. At least the savings due to the number of dependents causing increased consumption and increased holding money. Furthermore, the indirect effect of family size on the demand for holding cash money through financial investment and consumption of durable goods showed no significant effect on the whole. That is a lot or a little number of members kelaurga dependents will not be affected by changes in financial investment. Furthermore, also found no link between financial investment and consumption of durable goods, and then coupled with the lack of effect on the consumption of durable goods demand for holding cash money. This explains the many dependents do not affect the amount of savings and consumption, as well as holding money.

These results are not in accordance with the initial hypothesis which states that family size is no indirect effect on the demand for holding cash money through financial investment and consumption of durable goods. This result is also not in line with the theory of Tobin (1956) and Dunbar (2014) which menyatakn that the number of dependents of course will increase consumption, as well as holding money.Indirect positive relationship between family size and the demand for money when analyzed influence through consumption can then be inferred. By comparing the direct and indirect effect of family size on the demand for holding cash money, found the dominance of positive influence directly. Therefore, it can be said the total effect of family size on the demand for holding cash money shows a trend towards a positive and significant relationship. Based on these descriptions, the implication is that households rational thinking in asking for their cash due to the large demand for holding cash money according to the number of family dependents. The more the number of dependents, the more automatic the needs required for life, such as the number of people in the house dependents so the more routine expenses ie daily expenses for dining/kitchen needs (rice, side dishes and so on).

Table 2. Coefficient Estimation Results Direct and Indirect Effects

\begin{tabular}{|c|c|c|c|c|}
\hline \multirow{2}{*}{$\begin{array}{l}\mathrm{N} \\
\mathrm{O}\end{array}$} & \multirow{2}{*}{$\begin{array}{l}\text { Directions Influence } \\
\text { Between Variables / } \\
\text { Hypotheses Research }\end{array}$} & \multicolumn{3}{|c|}{ Figures Coefficient Estimation for Variable Effect } \\
\hline & & $\begin{array}{l}\text { Direct } \\
\text { Effect }\end{array}$ & Indirect Effect & Total Effect \\
\hline 1 & Hipotesis & & & \\
\hline & a) $x \rightarrow y_{3}$ & $0,109 *$ & & $0,13 *$ \\
\hline & throughy $_{1}$ & & 0,00408 & \\
\hline & throughy $_{2}$ & & 0,053301 & \\
\hline & throughy $_{1} \& \mathrm{y}_{2}$ & & 0,00083385 & \\
\hline & b) $x \rightarrow y_{1}$ & 0,051 & & 0,051 \\
\hline & c) $\mathrm{x} \rightarrow \mathrm{y}_{2}$ & 0,040 & & 0,025 \\
\hline & through $\mathrm{y}_{1}$ & & 0,00765 & \\
\hline
\end{tabular}

\section{Conclusion}

The conclusion of the research as follows: Effect of variable family size towards demand for holding cash money showed a positive and significant influence either Directly or indirectly through financial investment only.The amount of demand for holding cash money directly affected by the large number of family dependents. But if through financial investment and consumption of durable goods, the number of dependent family members does not affect the demand for holding cash money. The results of these studies reflect rational society in managing demand for holding cash money and reflect the transaction motives that can strengthen Keynes's theory about the motives of people holding money..

\section{Acknowledgements}

Thanks addressed to Prof. Dr. H Muhammad Yunus Zain, MA and Prof. Dr. Hj. Rahmahtia, MA, lecturer of Economic Department, Economic and Business Faculty, Hasanuddin University, who have guided the authors in completing this article. 


\section{References}

[1]. Carrassal, C M dan von Landesberger, (2010), “Explaining the Demand for Money by Non Financial Corporations In The Euro Area: A Macro and a Micro View". The Working Paper ISSN: 1579-8666 (on line) Documentos de Trabajo. No 10332010

[2]. Anderson, R E., (1976), “The Individual's Transaction Demand for Money”. Journal of Monetary Economics 2.2 (Apr 1976): 237256.

[3]. $\quad$ Mises, M. Von, (1921), "The Theory of Money and Credit". 3rd English edn, Indianapolis: Liberty Classics.

[4]. Ragot, Xavier, (2010), "The Case for a Financial Approach to Money Demand". Banque de France and Paris School of Economics. NBER Working Paper 14768.

[5]. Sousa, (2011), "International Transmission of Shocks, Money Illusion and the Velocity of Money". Discussion Paper No. 2011-49| November 25, 2011

[6]. Skouesen, Mark, (2005), "Sejarah pemikiran ekonomi sang maestro teori- teori ekonomi modern”, Prenada Media, Jakarta

[7]. Seitz, Franz dan Von Landesberger, J., (2014), "Household Money Holdings in the Euro Area: An Explorative Investigation". Journal of Banking and Financial Economics 2(2)2014, 83-115.

[8]. Keynes, J. M., (1936), “The General Theory of Employment, Interest and Money”. London: Macmillan.

[9]. Baumol, W., (1952), "The Transaction Demand for Cash: An Inventory Theoretic Approach". Quartery Journal of Economics 66, November, 545-56.

[10]. Tobin, J., (1956), “The Interest Elasticity of Transactions Demand for Cash". Review of Eonomics and Statistics 38, August, $241-7$.

[11]. Mizen, P D., (1997), "Microfoundations for a Stable Demand for Money". Economic Journal, Vol. 107 No. 443, July, pages 120212.

[12]. Shi, Shouyong, (2006), "Viewpoint: A Microfoundation of Monetary Economics". Canadian Journal of Economics/Revue canadienne d'Economique, Vol. 39, No. 3 August / ao^ut 2006. Canadian Economics Association.

[13]. Tin J., (2000), "Life Cycle Hypothesis, Propensity to Save, and Demand for Financial Assets". Journal of Economics and Finance, Vol. 24, No. 2 .

[14]. Tin J., (2010), "Bequest Motives and Household Money Demand”. Journal of Economics and Finance; Jul 2010; vol 34,no 3; ProQuest Health Management pg. 269

[15]. Dunbar, Georey, (2014), "Demographics and the Demand for Currency". Canadian Journal of Economics, Vol 46 (3), 811-835.

[16]. Attanasio O.P, (1997). "Cohort Analysis of Saving Behavior by US Household". The Journal of Human Resources, Vol XXXIII,3.

[17]. Hyunt K.N., (1979). "Rural Household Savings Behavior in South Korea 1962-1976". American Journal of Agricultural Economics, Vol. 61, No. 3, August.

[18]. Nugroho M.A.S dan Widiastuti N, (2003), "Pengaruh Relijiusitas, Pendapatan dan Tanggungan Keluarga terhadap Jumlah Tabungan”. Telaah Bisnis, Vol. 4, No. 2, Desember.

[19]. Gupta K.L, (1970), "On Some Determinants of Rural and Household Saving Behavior". Economic Record. December, 1970, p.578583.

[20]. Friedman M., (1957), “A Theory of The Consumption Function”. The National Bureau of Economic Research, Princeton University Press.

[21]. Gujarati. (2004). Basic Econometrics. Fourth Edition. (C) The McGraw-Hill Companies 